\title{
THE IMPLEMENTATION OF AN OPEN TEACHING POLICY IN OPEN EDUCATION IN MAURITIUS
}

\author{
Belle Louis Jinot ${ }^{\mathrm{i}}$ \\ Academic Affairs Division, \\ Open University of Mauritius, \\ Reduit, Mauritius
}

\begin{abstract}
:
This paper examines the implications of the implementation of a policy that promotes open teaching in an emerging open university. It describes the benefits and risks associated with such implementation within the context of Mauritius. It emphasises the adoption of cMOOCs which is more student-generated MOOCs that encourages student engagement based on socio-constructivism and heutagogy, instead of behaviourism and cognitivism. The use of open teaching promotes the democratisation of higher education and may help open universities to achieve economies of scale, and therefore making open universities profitable. However, open teaching through the adoption of cMOOCs may lack sustainability due to the political bearing of the open university concerning its governing bodies and the nomination of its head at the management level, the lack of electracy of a large number of contingent teaching staff as well as the lack of safeguard for the intellectual copyrights of MOOCs in Mauritius. It is recommended that open universities should invest massively in technology-enhanced content delivery and in the appointment of a graphic designer to support user-content generation.
\end{abstract}

Keywords: open teaching; implementation; cMOOCs; higher education

\section{Introduction}

In his speech for the first Convocation Ceremony in 2015, Dr. Leclezio, the Noble Prize Winner in Literature 2008, summarised the philosophy of the Open University of Mauritius (OUM): "This university is a symbol, to me: A university must not be a closed building; it must be a place opened to the whole world". With the increasing demand for higher education, on one hand, and the limited physical infrastructure of the brick-and-mortar university, on the other hand, the only way to educate the world is to open the doors to everyone who wants to study without borders and freely. The philosophy and actions of the OUM should be centered around the concept of openness in education: open access, open educational resources and open teaching, with the student being the user and the

i Correspondence: email 1.belle@open.ac.mu 
open participant in the learning process and product. OUM should not be an exception to other pioneers in open education such as the Open University of UK. It has to follow the trends, taking into consideration the benefits and risks that openness to education may imply.

It is urgent that OUM makes a shift from its instructed and behaviourist approaches to pedagogy to constructivist and connectivist approaches in an attempt to impact positively on education through technology. An overview of the changes in open education as well as the current developments in it is presented. To meet the challenges of high non-completion rate, delivering education to large cohorts of students and help students take ownership of their learning through co-creation and sharing of knowledge based on their own learning experience in a course or module, a policy for using the Massive Open Online Courses (MOOCs) in one module of the B Ed (Hons) Early Childhood Education and Care programme is recommended for implementation. Some potential risks are discussed in the report but risk-aversion brings an educational institution to no brighter future. Since open education is technology-driven, the OUM needs to invest in the appropriate technological, human, material and financial resources. The implementation of this policy is discussed here.

\section{Background}

Open education originated in the UK in the wake of the Plowden Report (1967). It was related to the physical layout of the primary school classroom spaces and approaches to designing instructional tasks (Jordan \& Weller, 2017). Walberg and Thomas (1972) made a distinction between traditional and open classes concerning provisioning, humaneness, diagnosis, instruction and evaluation, based on a survey carried out with teachers in the UK and the USA. Lewis (1986) discusses open education in terms of removing physical, education, individual and financial barriers in education. In the 1990s, open education was referred to technology-enhanced learning - using the internet and web-based technologies to improve teaching practices and learning (Jordan \& Weller, 2017). Open access publishing broadened the concept of openness in education during the 2000s. It focused on research output in higher education. Following the UNESCO Report (2002) on the impact of Open Courseware for higher education in developing countries, Hylen (2006) discussed issues related to Open Educational Resources (OERs), namely intellectual property, opportunities and challenges when involving in OERs. With the advent of social media like Web 2.0, online social networking tools are used as part of open practices (O'Reilly, 2005; Alexander, 2006; Moran, Seaman \& Tinti-Kane, 2011). Then, MOOCs have taken advantage of the digitalisation of the world to make access free to people (Daniel, 2012).

The main goal of open education was originally to provide access to education by removing all barriers to learning. According to Bates (2015), there should be no prior qualifications to entry, no discrimination by gender, age or religion, and affordability for every person, even for those with a disability. However, with the advent of the Open University of UK, open education not only implies accessibility, equal opportunity and 
open entry, but also transparency in terms of sharing of learning objectives with students, and the possibility of learning anywhere at the student's time and pace, and freedom of choices (Mishra, 2012; Cormier, 2013). It is about education for all, open access to awarded programmes and non-awarded programmes, open educational resources, open textbooks, open research and open data (Bates, 2015).

Open education is not only about making content available to students for free (Cormier, 2013) but learning should be based on behaviourism, cognitivism, socioconstructivism and connectivism, where students can think through the processes of inquiry, critical thinking, discussion and problem solving (Gibson, 2001). This is achieved through the use of technology, based on the Maddox (1986) Type II computer applications which consider that technology is used not only for knowledge instruction but also for knowledge construction (Dwyer, 1996). By using learning technologies such as Adaptive Learning Technologies, Mobile Learning, the Internet of Things, NextGeneration LMS, Artificial Intelligence and Natural User Interface (Adams-Becker, Cummins, Davis, Freeman, Hall-Glasinger \& Ananthanarayan, 2017), students have the opportunities to be actively engaged with the resources and content in a creative manner for their own learning, not only through self-directed learning but also through social interactions with other students and the teacher, who is rather an advisor or a guide instead of being "a sage on the stage", in the online environment (Kop, 2011; Gourlay, 2015). Hence, students can co-create and share learning materials and knowledge which is viewed by Gourlay (2015) as sui genesis. As such, open education is viewed as an emancipatory force (Lane, 2016), which enables students to map and remap on the acquired knowledge in an attempt to increase their understanding through networks, based on the cartography and decalcomania principles of Deleuze and Guattari (Cormier, 2012). With co-creation of content based on their learning experience in digital texts through social media platforms (White \& Le Cornu, 2011), students become part of the content, process and products of learning (DeRosa, 2016; Orr, van der Hijden, Rampelt, Röwert \& Suter, 2018). Besides, Mishra (2012) propounds that in the context of open education, the university must use alternative assessment methods, which are competence-focused (Strake, 2016), such as portfolios, projects, term papers and other evidence-based mechanisms that allow for assessing the student-led curriculum.

The three modes of openness are open access, open educational resources (OER) and open teaching (Wiley \& Green, 2012). According to the Open University learning model, education is open to people, places, methods and ideas (Mishra, 2012) with no formal entry qualifications (Lane, 2016). Open access provides freedom to enrol in a course for those who can pay for education and who feel they can participate in it (Gunawardena \& LaPointe, 2008). UNESCO (2017) defines OER as "any type of educational materials such as syllabi, assignments, textbooks, lecture notes, audio, videos, projects, tests, animations and curricula that are in the public domain or introduced with an open license. Anyone can legally and freely copy, use, adapt and re-share them". With the help of the internet, it allows the free sharing of educational resources among all students (Wiley \& Green, 2012). According to these two authors, open teaching is the practice of using technology to open university courses to encourage informal participation by those who are not 
enrolled in it. This can be done by posting syllabi and assignments on publicly viewed blogs. The open teaching model uses the Massive Open Online Course. A MOOC is a learning environment that encompasses a spectrum of course designs (Rodriguez, 2012). It offers learning resources and instructional services for large groups of students as well user forums to support learning through interactions (Li \& Zhou, 2018).

In the context of Open University of Mauritius (OUM), it is hereby suggested that the Senior Management Team (SMT) adopts the MOOC in a particular course, namely the B Ed (Hons) Early Childhood Education and Care programme to make it massive, open access and free.

This report examines the following questions:

(a) What does the adoption of the open teaching tool such as the MOOC entail for a young open university like the Open University of Mauritius?

(b) What are the potential benefits and risks in implementing such an open teaching policy?

\section{The MOOC As The Open Teaching Policy}

There are two strands of MOOCs, namely xMOOCs and cMOOCs. The XMOOC is an automated teacher-centred course that is directed and instructed to the students and provided in an online environment to many students (Kennedy, 2014). It, therefore, follows the behaviourist-cognitive approach to pedagogy. On the other hand, the cMOOC is based on the constructivist and connectivist approach, whereby students may create their knowledge together (Daniel, 2012). Examples of MOOCs platforms are Coursera, EDX, FutureLearn, Udacity and iVersity.

OUM uses the blended mode of teaching and learning and it has around 8000 students, most of them are working people. It employs only 22 full-time academics who lecture for tutorials on campus and manage all the programmes under their responsibility. The university has around 400 contingent or part-time lecturers for faceto-face and/or online tutorials.

For the policy of using a MOOC to teach one module, namely Learner Discipline Management, on a pilot basis first, the implementation process, put forward by the Early Childhood Technical Assistance Centre of the University of North California, is adopted. This implementation process consists of five stages, namely exploration, installation, initial implementation, full implementation and expansion or scale-up (Smith, Hurth, Pletcher, Shaw, Whaley, Peters \& Dunlap, 2014). Once, the policy is successful for the one module, it might be well expanded to the other modules over a period of two years.

\subsection{Exploration}

The SMT selects staff in the Academic Affairs Division who have the expertise in MOOCs and who are motivated to help to implement the policy. Due to the scarcity of in-house experts in MOOCs, the university hires external resource persons from another university who monitor the implementation phase. Their roles and responsibilities are clearly defined and they form part of the MOOC development committee that makes a 
needs analysis of the current situation about the delivery of modules in the specific programme in the university. The programme manager of the module presents the purpose and the value of the change towards openness to the experts, the SMT, the head of the university management, the B Ed (Hons) students as well as the contingent lecturers for the specific module as well as those of other modules in the programme.

This new policy of open teaching is an urgent requirement for the university in the context of a pandemic and with most students being practising teachers. The attendance rate for the 10 hours' face-to-face sessions per module per semester is around $60 \%$; the students have only a prescribed reading material per module, and they have to sit for a two hours' end-of-semester examination in each module. It is a growing university with a very small campus, not physically reachable by everyone in the country. Besides, students who do not attend on-campus tutorials do not score well in examinations. The online tutorials are often not followed by the working students and registered foreign students often face numerous difficulties to have a successful learning experience through online tutorials conducted on the ZOOM platform.

The vision of the institution is to become one of the best universities in the world and to increase the number of students to 10000 within the next five years. So, a change in educational policies, strategies and practice is required and there is the need for more openness to meet these challenges and address the issues of limited online tutorials in the Mauritius context.

\subsection{Installation}

The committee headed by the expert staff decides on building the system capacity for the successful implementation of the policy. The implementation drivers that are needed are a high-speed internet connection, the existence of a sustainable revenue model with the OUM being the only profitable public university with the highest annual student population growth, and the political will of the Senior Management Team. The committee develops an implementation plan by putting into action the five steps to success in a MOOC proposed by Dave Cormier, namely, orient, declare, network, cluster and focus (Stacey, 2013). This is likely to ensure the sustainability of the MOOC for further use by other student batches. A progress monitoring and evaluation schedule are drafted and training of all those involved here is done to ensure "training the trainers".

\subsection{Initial implementation}

The mechanisms to put in practice the MOOC is there. Therefore, based on the learning outcomes of the module, the students look for materials and links to be used each week, and the time for live sessions over the first four weeks are agreed. The part-time tutor monitors the readings of the students. They place their thoughts and reflections about their readings on learner discipline management in a blog or Personal Learning Network. They build their network to make connections among themselves and others who comment on the module. After these weeks, they cluster all the thoughts to develop their knowledge. By focusing on the learning outcomes of the module, they are likely to increase their knowledge of the content. The trained staff in the Academic Affairs 
Division and the programme manager support the students and the part-time tutor in creating the knowledge and provide feedback to the SMT and the head of the university management. Based on the feedback, the latter in consultation with the experts initiate the improvement cycles.

\subsection{Full implementation}

The new educational practice in terms of the implementation of the MOOC is closely monitored to ensure that it is used with high fidelity. The performance of the students is evaluated using alternative methods such as portfolio and projects instead of an end-ofterm written examination in the module. Any movement away from the established practice is identified and addressed immediately to ensure sustainability.

\subsection{Expansion/Scale-up}

The success of the MOOC of the module learner discipline management is likely to drive the immediate implementation of MOOCs in the other three modules of the semester. So, this new practice may become the standard for the remaining modules in the B Ed (Hons) Early Childhood Education and Care programme. More staff should be trained and more funding will, of course, be required.

\section{Benefits}

OUM is partially funded by the state. With the use of this MOOC, it may enjoy economies of scale as it may deliver teaching and learning to a large number of B Ed (Hons) students. At the same time, it may reduce its face-to-face sessions as the approach is now more user-focused and knowledge-creation. Instructed learning is required to a lesser extent. In addition, it may use the MOOC for registering pre-school teachers to complete one or two modules and obtain certification towards their continuous professional development as per the Pay Research Bureau recommendations for medical practitioners in Mauritius. The university may collect fees for certificate issue. So, the revenue of OUM may increase. Also, there will be no need for OUM to invest money in building new campuses to reach the students as learning takes place online through MOOCs.

Students take ownership of their learning as they have the freedom of choice to co-create their knowledge (freedom to select and edit photos, mount videos and create audios about their learning experience), share it by staying connected through comments and posts on YouTube or soundcloud. So, an autonomous and motivated community of practice is set up among themselves who are open participants. So, there is more interaction through peer learning. Besides, they are assessed on the knowledge gained from their learning experience through a portfolio or a project, not in a two-hour examination paper through rote learning without understanding. 


\section{Risks}

The head of the university management and the Management Board of OUM are politically appointed. So, a newly appointed head of the university and a new Management Board may not adhere to cMOOCs as an educational practice but rather instruct the Academics to produce traditional video presentations (xMOOCs) and provide them at a cost to students. So, there is a risk of a lack of sustainability of the full implementation of the policy in the coming years. MOOCs. So, the sustainability of the MOOC may be at stake with political change at the national level.

The experienced B Ed (Hons) students are visitors rather than residents on the OULearn platform or they may be considered as digital immigrants who lack the critical literacies and technological competencies to use ICT applications to connect, comment and communicate among themselves online. For instance, many among them do not know how to send and reply to a mail from the student E-Learn Platform of the university. So, many of them may not be able to actively participate in the process of knowledge construction. On the other hand, the PT tutors may not be willing to learn how to teach online effectively as contingent resource persons are mostly retired persons with teaching experience in the traditional brick and mortar buildings. They may also lack electracy. This is may lead to a high drop-out rate in the programme.

Students from Rodrigues Island and in some remote places in Africa may feel isolated as they have an internet connectivity problem. Also, the intellectual copyrights of the students in the co-creation of knowledge may not be safeguarded due to a lack of security and transparency in MOOCs.

\section{Recommendations}

For the implementation of the policy on the MOOC, the OUM needs to invest in LectureScape, which is an enhanced content delivery technology. It is a video player that is powered by a set of data-driven video interaction techniques that enhance video timeline and test search. It augments existing video interface widgets. The videos that the PT tutors or other resource persons and the B Ed (Hons) students produce may be made easier for rewatching, skimming, searching and reviewing. It also automatically creates word clouds and summaries. This technology makes the MOOC more personalised and interactive for the students.

A graphic designer is required to assist the programme manager and the PT tutors in using this technology and other relevant and useful technologies and ICT applications to administer the MOOC effectively and constructively. The job description of this post should be written by the HR department to enable the implementation of the policy. Some PT tutors and full-time academics should be given the facility to use the university studio to produce videos that are enhanced by LectureScape under the supervision of a MOOC coordinator. The latter is required to work in close collaboration with the programme manager, the PT tutors and the students. He/she will ensure that all of them are fully engaged in the process of the MOOC in the module: "No one should be left behind" 
in the process and the practice of open education, as the product (effective teaching and learning through co-creation, participation and sharing) is equally important.

\section{Conclusion}

This report gives an overview of the potential implications of implementing a pedagogical change in the teaching approach of the Open University of Mauritius. The adoption of open teaching through the use of cMOOCs enables the practice of effective andragogy as Open Universities enrol mostly working adult learners, who have many personal and professional experiences to share and to make their learning and that of their remote classmates more meaningful and sense-making. It is in line with selfdirected learning. Teacher-led knowledge is too prescriptive and exclusive in the context of open education whereby remote students should feel rather more inclusive and be part of their learning through a community of inquiry that may be formed when knowledge is generated through student engagement in the virtual learning environment.

\section{Conflict of Interest Statement}

The authors declare no conflicts of interests.

\section{About the Author}

Dr. Belle Louis Jinot is an academic at the Open University of Mauritius. He currently serves as a lecturer and Programme Leader in the field of Educational Leadership and Management. He holds a D. Ed in Education Management. He is a Commonwealth scholar (MA Online and Distance Education from the Institute of Technology Education, The Open University, UK) and he is currently an Association of Commonwealth Universities Fellow in Education at Bayero University, Kano, Nigeria. His areas of interest are technology-enhanced education, educational leadership and management, school principalship. He has widely published in the field of educational management.

\section{References}

Adams-Becker, S., et al. (2017). NMC Horizon Report Higher Education Edition. Austin, Texas: The New Media Consortium.

Alexander, B. (2006) Web 2.0: A new wave of innovation for teaching and learning. EDUCAUSE Review.

Bates, T. (2015). What do you mean by open education? [Online]. Available at https://www.tonybates.ca/2015/02/16/what-do-we-mean-by-open-in-education/ (Accessed 15 March 2021)

Cormier, D. (2012). Embracing uncertainty and the strange problem of habituation [Online]. Available at http://daavecormier.com/edblog/2012/01/26/embracing-uncertaintyand-the-starnge-problem-of-habituation/ (Accessed 30 April 2021) 
Cormier, D. (2013). What do you mean ...open? [Online]. Available at http://davecormier.com/edblog/2013/04/12/waht-do-you-mean-open/ (Accessed 25 April 2021)

Daniel, J. (2012). Making sense of MOOCs: Musings in a maze of myth, paradox and possibilities. Journal of Interactive Media in Education, 3(18). [Online]. Available at http://dx.doi.org/10.5334/2012-18 (Accessed 26 April 2021)

DeRosa, R. (2016). My open textbook: Pedagogy and practice [Online]. Available at http://robinderosa.net/uncategorised/my-open-textbook-pedagody-and-practice/ (Accessed 30 April 2021)

Dwyer, D. C. (1996). The imperative to change our schools, in C. Fisher, D. Dwyer \& K. Yocam (Eds). (1996). Education and Technology: Reflections on computing in classrooms. San Francisco: Jossey-Bass.

Gibson, I. W. (2001). At the intersection of technology and pedagogy: Considering styles of learning and teaching. Journal of Information Technology for Teacher Education, 10(1): 37-61 [Online]. Available at https://doi.pog/10.1080/14759390100200102 (Accessed 17 April 2021)

Gourlay, L. (2015). Open education as a 'heterotopia of desire. Learning, media and Technology, 40(3): 310-327 [Online]. Available at https://doi.org/10.1080/17439884.2015.1029941 (Accessed 10 April 2021)

Gunawardena, C., \& LaPointe, D (2008). Social and cultural diversity in distance education, in Evans, T., Haughey, M., \& Murphy, D. (Eds.). International Handbook of Distance Education, 15(1): 51-70. Bingley: Emerald Publishing.

Hylen, J. (2006). Open educational resources: Opportunities and challenges. OECD.

Kennedy, J. (2014). Characteristics of massive open online courses (MOOCs): A Research review, 2009-2012. Journal of Interactive Online Learning, 13(1): 1-16.

Kop, R. (2011). The challenges to connectivist learning in open online networks: Learning experiences during a massive open online course [Online]. Available at https://www.irrodl.org/index.php/irrodl/rt/printerfriendly/882/1689 (Accessed 30 April 2021)

Lane, A. (2016). Emancipation through open education: Rhetoric or reality? In: Blessinger, Patrick and Bliss, TJ eds. Open Education: International Perspectives in Higher Education. Open Book Publisher, 31-50.

Lewis, R. (1986). What is open learning? Open Learning: The Journal of Open Distance and eLearning, 1(2): 5-10.

Li, C., \& Zhou, H. (2018). Enhancing the efficiency of massive online learning by integrating intelligent analysis into MOOCs with an application to education and sustainability. Sustainability [Online]. DOI: 10.3390/su/8410020468. Available at www.mdpi.cjournal/sustainability (Accessed 15 April 2021)

Maddox, C. D. (1986). Issues and concerns in special education microcomputing. Computers in the Schools, 2(3): 3.

Mishra, S. (2012). Openness in education: Some reflections on MOOCs, OERs and OD. Commonwealth of Learning. 
Moran, M., Seaman, J., \& Tinti-kane, H. (2011). Teaching, learning and sharing: How today's high education faculty use social media for work and for play. Pearson.

O'Reilly, T. (2005). What is Web 2.0? Design patterns and business models for the next generation of software.

Orr, D., van der Hijden, P., Rampelt, F., Rowert, R., \& Suter, R. (2018). Towards a Bologna Digital Strategy for higher education. University World News, no. 504 [Online]. Available http://www.universityworldnews.com/article.php?story $=2018050410025729$ (Accessed 1 May 2021)

Rodriguez, O. (2012). MOOCs and the AI-Stanford like courses: Two successful and distinct course formats for massive open online courses. European Journal of Open, Distance, and E-Learning [Online]. Available at http://www.eurodl.org/materials/contrib/2012/Rodriguez.pdf (Accessed 26 April 2021)

Smith, B., Hurth, J., Pletcher, L., Shaw, E., Whaley, K., Peters, M., \& Dunlap., G. (2014). A guide to the implementation process: Stages, steps and activities. ECTA Centre: University of North California.

Stacey, P. (2013). The Pedagogy of MOOCs. [Online]. Available at https://edtechfrontier.com/2013/05/11/the-pedagogy-of-moocs/ (Accessed 30 March 2021)

Stracke, M. M. (2016). Open Learning for smart education: open educational practices, strategies and access for all. IEEE Education, Open University of Netherlands.

UNESCO. (2017). Communication and information, "What are open educational resources (OERs)? Anline]. Available at http://www.unesco.org/new/en/communication-and-information/acess-toknowledge/open-educational-resources/what-are-open-educational-resourcesoers/ (Accessed 25 March 2021)

Walberg, H. J., \& Thomas, S. C. (1972). Open education: An operational definition and validation in Great Britain and the USA. American Educational Research Journal, 9(2): 197-208.

White, D. S., \& Le Cornu, A. (2011). Visitors and residents: A new typology for online engagement. First Monday, 16(9). [Online]. Available at http://firstmonday.org/ojs/index.php/fm/article/view/3171/3049 $\quad$ (Accessed 17 April 2021)

Wiley, D., \& Green, C. (2012). Chapter 6: Why openness in education? [Online]. Available at https://library.educause.edu/resources/2012/5/chapter-6-why-openness-ineducation/ (Accessed 4 May 2021) 
Creative Commons licensing terms

Authors will retain the copyright of their published articles agreeing that a Creative Commons Attribution 4.0 International License (CC BY 4.0) terms will be applied to their work. Under the terms of this license, no permission is required from the author(s) or publisher for members of the community to copy, distribute, transmit or adapt the article content, providing a proper, prominent and unambiguous attribution to the authors in a manner that makes clear that the materials are being reused under permission of a Creative Commons License. Views, opinions and conclusions expressed in this research article are views, opinions and conclusions of the author(s). Open Access Publishing Group and European Journal of Open Education and E-learning Studies shall not be responsible or answerable for any loss, damage or liability caused in relation to/arising out of conflict of interests, copyright violations and inappropriate or inaccurate use of any kind content related or integrated on the research work. All the published works are meeting the Open Access Publishing requirements and can be freely accessed, shared, modified, distributed and used in educational, commercial and non-commercial purposes under a Creative Commons Attribution 4.0 International License (CC BY 4.0). 